Volume 2

Issue 4 -- Integrative Medicine

Article 4

$11-20-2015$

\title{
Essentials of Herb-Drug Interactions in the Elderly With Cardiovascular Disease
}

Sulaiman Sultan

Maria Viqar

Rabaiya Ali

A. Jamil Tajik

Arshad Jahangir

Follow this and additional works at: https://aah.org/jpcrr

Part of the Alternative and Complementary Medicine Commons, Biological Factors Commons, Cardiovascular Diseases Commons, Chemical Actions and Uses Commons, and the Integrative Medicine Commons

\section{Recommended Citation}

Sultan S, Viqar M, Ali R, Tajik AJ, Jahangir A. Essentials of herb-drug interactions in the elderly with cardiovascular disease. J Patient Cent Res Rev. 2015;2:174-191. doi: 10.17294/2330-0698.1212

Published quarterly by Midwest-based health system Advocate Aurora Health and indexed in PubMed Central, the Journal of Patient-Centered Research and Reviews (JPCRR) is an open access, peer-reviewed medical journal focused on disseminating scholarly works devoted to improving patient-centered care practices, health outcomes, and the patient experience. 


\title{
Essentials of Herb-Drug Interactions in the Elderly With Cardiovascular Disease
}

\author{
Sulaiman Sultan, MD, ${ }^{1,2}$ Maria Viqar, MD, ${ }^{3}$ Rabaiya Ali, MD, ${ }^{1}$ A. Jamil Tajik, MD, ${ }^{4}$ Arshad Jahangir, MD ${ }^{1,4}$ \\ ${ }^{1}$ Sheikh Khalifa bin Hamad Al Thani Center for Integrative Research on Cardiovascular Aging (CIRCA), \\ Aurora Research Institute, Aurora Health Care, Milwaukee, WI \\ 2Internal Medicine, Aurora Health Care, Milwaukee, WI \\ ${ }^{3}$ Cardiac Electrophysiology, Dallas Medical Physician Group, Dallas, TX \\ ${ }^{4}$ Aurora Cardiovascular Services, Aurora Sinai/Aurora St. Luke's Medical Centers, Aurora University of Wisconsin \\ Medical Group, Milwaukee, WI
}

\begin{abstract}
As the number of individuals, particularly the elderly, using herbal products with prescription drugs continues to grow, the risk for adverse interactions increases but remains poorly recognized. The true incidence and nature of adverse herb reactions or herb-drug interactions remains unknown since no postmarketing surveillance mechanism exists. Adverse events are greatly underreported, and information regarding safety mainly comes from case reports and suboptimally conducted studies in a limited number of healthy young volunteers or patients with limited comorbidities. Therefore, convincing evidence for the safety of herbal products in the elderly is lacking, and the true magnitude of problems that herb-drug interactions pose to public health, particularly in elderly patients with cardiovascular diseases, is not known. Since cardiovascular diseases themselves are life-threatening, necessitate use of multiple medications and occur in a population with extensive comorbidities, the risk of herb-drug and herb-disease interactions is not minor and cannot be ignored. This review addresses these concerns in an effort to raise awareness about the use of herbal medicine by the elderly and its potential adverse impact on the efficacy of prescription medications that can increase predisposition to catastrophic events such as major bleeding, inadequate anticoagulation leading to undesired clotting, transplant organ rejection and life-threatening cardiac arrhythmias. (J Patient-Centered Res Rev. 2015;2:174-191.)

Keywords complementary therapy, herb, integrative medicine, cardiovascular agents, elderly, herb-drug interaction
\end{abstract}

The use of herbal and dietary supplements continues to increase, rising from $2.5 \%$ in 1990 to $12.1 \%$ in $1997,{ }^{1-3}$ with a 2007 National Health Interview Survey showing that U.S. adults annually spend more than $\$ 33.9$ billion out of pocket on complementary health approaches. ${ }^{4}$ Nonvitamin, nonmineral dietary supplement use $(17.9 \%)$ was greater than any other complementary health approach per another national survey from 2012 (Figure 1). ${ }^{5}$ Total sales of herbal and dietary supplements in 2013 was reported to be $7.9 \%$ higher than 2012, making the 10th year in a row in which herb sales increased over the previous year. ${ }^{6}$ Sales of the

Correspondence: Arshad Jahangir, MD,

2801 W. Kinnickinnic River Parkway, Milwaukee, WI,

53215, T: 414-649-3909; F: 414-649-3551,

Email: publishing44@aurora.org top 10 herbal supplements in 2012 are summarized in Table $1,{ }^{7}$ and the global herbal market for 2015 is projected to be greater than $\$ 93$ billion. ${ }^{8}$

Natural products - including vitamins, herbs, amino acids, minerals and probiotics — are often sold as dietary supplements and regulated as food products by the U.S. Food and Drug Administration (FDA). Unlike allopathic medicines, these supplements do not need FDA approval of their safety and efficacy. Since the use of herbal products is increasing, particularly by elderly patients who also use medicinal products, the likelihood of adverse interactions is rising. ${ }^{9}$ Nahin and colleagues, ${ }^{10}$ investigating the relationship between prescription medications and supplements in patients age 75 years or older, showed that $82.5 \%$ of patients used at least one supplement and 54.5\% used three or more; the average number of prescription medications 
Figure 1. Percentage of U.S. adults who used complementary health approaches, by type, in the past 12 months (2012). ${ }^{5}$ Note: Not all complementary health approaches are presented in this figure. Source: www.cdc.gov/nchs/data/databriefs/db146.pdf.

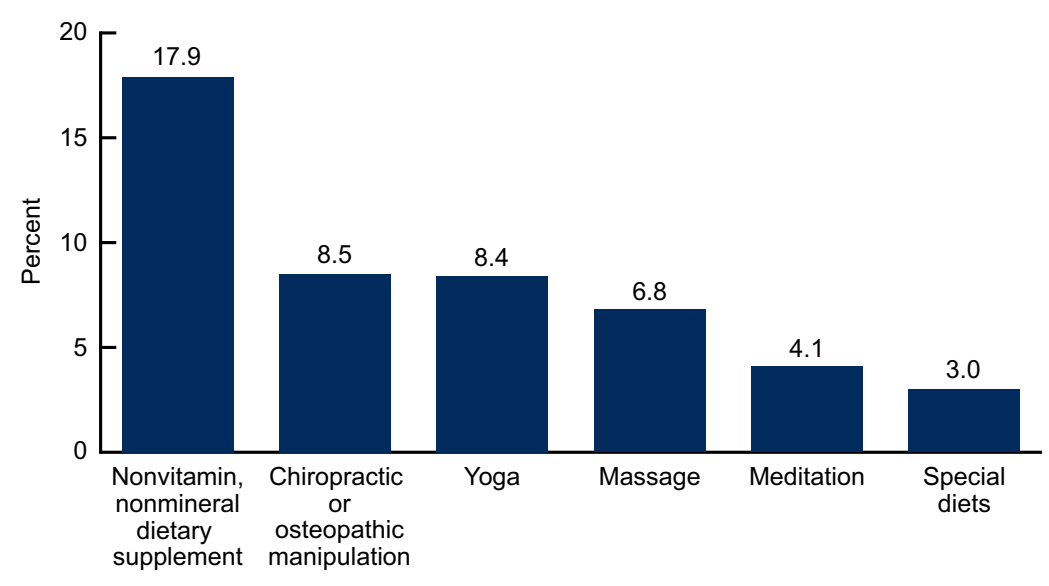

used per patient was 3.5, which was similar to the average number of dietary supplements used by the same population.

Although drug-drug interactions are typically taken into account, the importance of herb-drug interactions is slowly being recognized as a potential factor affecting outcomes in the elderly, especially those with multiple comorbidities, ${ }^{11-13}$ polypharmaceutical use ${ }^{14}$ and aging-associated physiological changes that alter pharmacokinetics and pharmacodynamics. ${ }^{15}$ Drugs with a narrow therapeutic index, such as anticoagulants, chemotherapeutics, organ antirejection agents and antiarrhythmic compounds, are particularly vulnerable to interaction.

The majority of patients taking herbal supplements do not disclose such to health care professionals. ${ }^{16}$ Thus, the risk for potential interactions between supplements and medications can go undetected; therefore, it is important for providers and patients to educate themselves. ${ }^{17,18}$ In this review we describe common herbal remedies used by the elderly and their potential interactions with cardiovascular drugs. We also highlight regulatory issues regarding herbal supplements and discuss possible ways to improve safety and minimize adverse effects.

\section{Search Strategy and Selection Criteria}

We searched Medline, the National Center for Complementary and Integrative Health (NCCIH) website, the Natural Standard Research Collaboration at Medline Plus ${ }^{19}$ and the Cochrane database from 1966 to February 2015 for information on herbal products using the key words herbs, herb-drug interactions, complementary and alternative medicine, cardiovascular diseases, elderly and each of the individual herbs discussed in this review. We also manually searched references and articles written with a focus on the risk of herb-drug interactions, particularly those used in the care of patients with cardiovascular diseases.

\section{Factors Affecting Herb-Drug Interactions in the Elderly}

Factors contributing to drug-herb interactions include patient-related factors (age, body size/composition, metabolism and kidney function, genetics, lifestyle and comorbidities) as well as drug- and herb-related factors (amount, route and time of administration). This is particularly relevant to the elderly in whom the chances for adverse interactions are higher due to presence of aging-associated comorbidities, ${ }^{11}$ use of polypharmacy ${ }^{14}$ and reduced functional reserves. ${ }^{20}$ Poor nutritional status, impaired organ function and genetic variants in drug metabolism are other factors that increase predisposition to adverse interactions. ${ }^{21-28}$ With aging, drug metabolism and elimination pathways also are affected by changes in the liver or intestinal membranes harbouring the cytochrome P450 enzyme superfamily or other enzymes that metabolize drug to a form that can then be eliminated through the kidney or the gut. This is especially true for interactions between herbs, such as St. John's wort or grapefruit juice, that have inhibitory effects on CYP3A4 enzymes or P-glycoprotein transporter protein. $12,13,29,30$

Aging is associated with a reduction in kidney mass, renal blood flow and the number of functioning glomeruli that reduces kidneys' ability to eliminate drugs, resulting in prolongation of their elimination half-life and potential 
Table 1. The 10 top-selling herbal dietary supplements in the food, drug and mass market channel in the United States for $2012^{7}$ (per SymphonyIRI Group*)

\begin{tabular}{ll}
\hline Herb (Latin Name) & $\begin{array}{l}\text { Sales } \\
\text { (in U.S. dollars) }\end{array}$ \\
\hline 1. Cranberry (Vaccinium macrocarpom) & $\$ 65,483,940$ \\
2. Garlic (Allium sativum) & $\$ 34,950,540$ \\
3. Saw palmetto (Serenoa repens) & $\$ 31,775,810$ \\
4. Soy (Glycine max) & $\$ 28,017,310$ \\
5. Ginkgo (Ginkgo biloba) & $\$ 25,853,420$ \\
6. Milk thistle (Silybum marianum) & $\$ 21,143,560$ \\
7. Black cohosh root (Actae racemosa ${ }^{\dagger}$ ) & $\$ 16,925,990$ \\
8. Echinacea (Echinacea spp.) & $\$ 15,898,880$ \\
9. St. John’s wort (Hypericum & $\$ 12,193,790$ \\
perforatum) & $\$ 11,136,960$ \\
\hline
\end{tabular}

*Source of data: SymphonyIRI Group Inc., a Chicago-based market research firm. "FDM market sales data for herbal supplements, 52 weeks ending December 23, 2012."

†Synonym: Cimicifuga racemosa.

${ }^{\ddagger}$ Echinacea collectively refers to supplements made from roots and/or aerial parts of plants from three species in the genus Echinacea, including E. angustifolia, E. pallida and E. purpurea.

$\S$ It is not clear from the SymphonyIRI data whether this figure also includes the sales of American ginseng root products (made from Panax quinquefolius), the sales of which are not as high as sales of supplements made from Asian ginseng (P. ginseng).

for adverse effects. There is limited data on drug-herb interactions in the elderly, particularly those 80 years and older, who are at higher risk of adverse interactions with drugs that have a narrow therapeutic index, such as anticoagulants and sedatives..$^{31,32}$

Common herbal remedies and their potential interactions with drugs that produce adverse effects on the cardiovascular system are summarized in Online Supplemental Appendix 1. We have narrowed this review to the purported use, potential side effects and interactions of the top 10 selling plant products (per a SymphonyIRI Group report ${ }^{7}$ ) and grapefruit juice with drugs used in cardiovascular medicine in the elderly.

\section{Cranberry}

Cranberry (Vaccinium macrocarpton) fruits and extracts have been used in traditional medicine to treat urinary tract infections (UTI), diabetes, H. pylori-induced gastric ulcers, and blood and digestive disorders. The exact mechanism of action is not known, but the inhibitory effect of cranberry proanthocyanidins on growth, adhesion and virulence of $E$. coli bacteria has been suggested to prevent infections. ${ }^{18}$ Although a few small studies demonstrated benefit from cranberry use in women with recurrent UTIs, a 2012 Cochrane review showed no statistically significant differences when the results of a much larger study were included and recommended against the use of cranberry for UTI prevention. ${ }^{33}$ This inconsistency in study results could be due to the variability in study designs, cranberry products used, study compliance or differences in pathogenesis of UTI in different groups such as young children, sexually active young adults or the elderly. Some case reports in the elderly ${ }^{34,35}$ reported raised international normalized ratio (INR) and life-threatening bleeding with coadministration of warfarin and cranberry. In 12 young healthy volunteers, a single dose of warfarin after 2 weeks of cranberry juice consumption caused a 30\% elevation in INR, ${ }^{36}$ suggesting the potential for adverse event may be higher in elderly patients who have multiple comorbidities. Therefore, cranberry juice should be avoided in patients on chronic anticoagulant therapy. Some studies have reported that cranberry juice inhibits CYP2C9 and CYP3A4, ${ }^{37}$ however, others have not confirmed these findings. ${ }^{38}$ Due to these inconsistent findings, additional research is warranted to clarify cranberry's efficacy and safety in the elderly with multiple comorbidities. ${ }^{33}$

\section{Garlic}

Garlic (Allium sativum), a medicinal herb, has many potential benefits with its antimicrobial, immuneenhancing and anticholesterolemic effects, and is widely used for heart disease, high blood pressure, high cholesterol and prevention of stomach and colon cancers. Some clinical studies have shown aged garlic extract to be a safe adjunct treatment to conventional antihypertensives $^{39}$ and to improve glycemic control and lipid profile when used in combination with antidiabetics. ${ }^{40}$ An enhanced antihyperglycemic response was described in a woman on chlorpropamide after eating a curry containing garlic and Momordica charantia 
(bitter melon), another plant product used for medicinal purposes. ${ }^{41}$ Garlic is used as a dietary supplement by patients infected with human immunodeficiency virus (HIV) and can cause detrimental effects, including severe gastrointestinal toxicity, when coadministered with protease inhibitors like ritonavir. ${ }^{42}$ In a controlled trial of patients with coronary artery disease randomized to receive either garlic oil (4 g/day) or placebo taken with prescribed nitrates, garlic significantly decreased total serum cholesterol and increased serum highdensity-lipoprotein cholesterol. ${ }^{43}$ However, other trials have shown no significant effects on total cholesterol, low-density-lipoprotein cholesterol, blood pressure, platelet count or triglycerides in patients taking garlic supplements. ${ }^{36,44}$

Garlic is believed to have antithrombotic activity ${ }^{45}$ and decrease platelet aggregation, ${ }^{46}$ which can increase clotting time and risk of bleeding when taken with anticoagulants such as warfarin. ${ }^{47}$ However, in healthy volunteers, garlic in combination with warfarin was shown to have no effect on INR or bleeding risk over short-term follow-up. ${ }^{36,44}$ Garlic should be used with caution in those on oral anticoagulants, as garlicassociated postoperative bleeding ${ }^{48}$ and spontaneous spinal epidural hematoma ${ }^{49}$ have been reported. It is recommended that garlic supplements be discontinued about 10 days before elective surgical procedures, especially in patients on antiplatelet agents or anticoagulants. ${ }^{48}$

\section{Saw Palmetto}

Saw palmetto (Serenoa repens), an extract of the ripe berries of the American dwarf palm, is the most widely used phytotherapeutic agent for benign prostatic hyperplasia. Other purported uses include treatment of genitourinary conditions, for augmentation of breast size, to increase libido and sperm production, and as a mild diuretic. While there is some ambiguity around its mechanism of action, saw palmetto has demonstrated inhibitory effect on prostatic estrogen receptors ${ }^{50}$ and antiandrogen activity ${ }^{51}$ including inhibition of 5-alpha reductase, ${ }^{51,52}$ the enzyme responsible for conversion of testosterone to its active metabolite dihydrotestosterone. Earlier studies reported short-term efficacy of saw palmetto in ameliorating benign prostatic hyperplasia symptoms; ${ }^{53}$ however, this claim has been refuted in subsequent studies. In a randomized, double-blind study of saw palmetto using standard dose (320 mg/day) for a year, Bent and colleagues ${ }^{54}$ failed to demonstrate benefits in improving symptoms or objective measures of benign prostatic hyperplasia over placebo. Tacklind et al.'s Cochrane review demonstrated similar negative results of saw palmetto, even at higher doses, ${ }^{55}$ which was confirmed in a more recent trial (CAMUS) funded by the NCCIH that used up to $960 \mathrm{mg}$ /day of saw palmetto extracts in men with moderate lower urinary tract symptoms. ${ }^{56}$

Reported adverse reactions from saw palmetto include sexual dysfunction, fatigue, tachycardia, angina pectoris, extrasystole, ${ }^{57}$ hypertension,${ }^{58}$ intraoperative hemorrhage, ${ }^{59}$ bleeding susceptibility, ${ }^{60}$ pancreatitis ${ }^{61}$ and cholestatic hepatitis. ${ }^{62}$ In vitro studies suggest that saw palmetto inhibits some cytochrome P450 isoenzymes, including CYP2D6, CYP2C9 and CYP3A4. ${ }^{63}$ However, human studies indicated no clinically relevant effect on the majority of cytochrome P450 isoenzymes. ${ }^{64}$ Published reports of elevated INR in a patient on warfarin after taking a saw palmetto-containing product (curbicin) that normalized after discontinuation of curbicin $^{65}$ and excessive bleeding in a middle-aged man undergoing a surgical procedure to remove a brain tumor raise concerns regarding the risk of bleeding. ${ }^{59}$

\section{Soy}

Soy, obtained from Glycine $\max$ (fam. Fabaceae), a plant in the pea family, has been used in Japanese cuisine for thousands of years, with a recent boost in sales of soy phytoestrogens in American markets after publication of a study by the Women's Health Initiative showing harmful effect of estrogen-progestin combination and the belief that natural phytoestrogens may safely prevent bone loss and the consequences of estrogen deficiency without harmful effects. ${ }^{66}$ It is sold as food (tofu, soy milk) or dietary supplements (tablets, capsules). Purported benefits of soy protein include alleviation of menopausal symptoms, osteoporosis and hyperlipidemia. Soy protein products contain bioactive phytoestrogens or isoflavones, which have partial estrogen agonist and antagonist properties. ${ }^{67}$ Earlier studies demonstrating soy protein's beneficial effects on low-density-lipoprotein cholesterol and other cardiovascular risk factors or in reducing hot flashes in women ${ }^{68,69}$ were not confirmed by more recent studies. ${ }^{70}$ Mixed estrogenic and antiestrogenic properties of 
isoflavones make their effects on cancers complex, and it remains to be determined if isoflavone supplements increase the risk of endometrial hyperplasia. ${ }^{71}$

The long-term safety of soy isoflavones has not been established. Controversy exists regarding the beneficial effect of soy food versus isoflovane aglycones in promoting mammary and endometrial carcinogenesis in animal models, ${ }^{72,73}$ and its use should be avoided in women with breast cancers or other hormone-sensitive tumors. Soy isoflavones decrease the absorption of levothyroxine and should not be used in conjunction. ${ }^{74}$ Soy can inhibit CYP3A4 and CYP2C in vitro. ${ }^{75}$ Fermented soybean contains high level of vitamin $\mathrm{K}$ and may decrease the activity of warfarin or other anticoagulants. ${ }^{76}$ Cases of botulism from homefermented tofu have been reported..$^{77}$ Natto, a Japanese food made from fermented soybean containing high levels of vitamin $\mathrm{K}$, strongly antagonized the effects of warfarin in experimental models, ${ }^{78}$ markedly reduced the effects of acenocoumarol, a warfarin-derivative anticoagulant, ${ }^{79}$ and decreased INR to subtherapeutic levels when coadministered with warfarin ${ }^{76}$ (Table 2).

Table 2. Common herbs interacting with warfarin

\begin{tabular}{cc}
\hline $\begin{array}{c}\text { Herbs that increase } \\
\text { anticoagulant effect } \\
\text { (potentiate risk of } \\
\text { bleeding) }\end{array}$ & $\begin{array}{c}\text { Herbs that decrease } \\
\text { anticoagulant effect } \\
\text { (potentiate risk of } \\
\text { thromboembolism) }\end{array}$ \\
\hline Alfalfa & $\begin{array}{c}\text { Camellia sinensis } \\
\text { Coenzyme Q } \\
\text { Angelica } \\
\text { Bilberry }\end{array}$ \\
Cannabis & Ginseng \\
Capsicum & Soya \\
Cat's claw & St. John's wort \\
Chamomile & \\
Clove & \\
Cranberry & \\
Danshen & \\
Devil's claw & \\
Fenugreek & \\
Fever few & \\
Garlic & \\
Ginger & \\
Ginkgo biloba & \\
Grapefruit juice & \\
Kava & \\
Kelp & \\
Lycium & \\
Motherwort & \\
Red clover & \\
Saw palmetto & \\
Yohimbine & \\
\hline
\end{tabular}

\section{Ginkgo}

Ginkgo derived from the Ginkgo biloba leaf is popular and one of the most widely used herbal medicines in the world. Its active constituents are terpenoids, flavonoids and ginkgolides $\mathrm{A}, \mathrm{B}$ and $\mathrm{C}$, which have purported beneficial effects for Alzheimer's dementia, ${ }^{80}$ senile macular degeneration, tinnitus ${ }^{81}$ and peripheral arterial disease. ${ }^{82}$ Overall the evidence for ginkgo's beneficial effect in patients with dementia or cognitive impairment is inconsistent in the literature, and the majority of trials report no significant difference between ginkgo and placebo in improving dementia or cognitive impairment. ${ }^{83}$ Ginkgo biloba extracts can inhibit thromboxane A2 synthesis ${ }^{84}$ and have inhibitory effects on platelet aggregation through increase in cyclic adenosine monophosphate, cyclic guanine monophosphate production and matrix metalloproteinase- 9 activation, or inhibition of plateletactivating factor. ${ }^{85,86}$ Therefore, there is concern regarding increased risk of bleeding with ginkgo when coadministered with anticoagulants (Table 2) or antiplatelet drugs such as ticlopidine. ${ }^{87}$ Bleeding events attributed to ginkgo use in warfarin-associated intracerebral hemorrhage, ${ }^{88}$ ibuprofen-associated intracerebral mass bleeding, ${ }^{89}$ aspirin-associated spontaneous hyphema, ${ }^{90}$ postoperative bleeding ${ }^{91}$ and subphrenic hematoma requiring laparoscopic evacuation $^{92}$ have been reported.

Clinical studies in healthy volunteers over short-term follow-up are presented as evidence for ginkgo's safety and lack of significant effect on blood coagulation or platelet function. ${ }^{93,94}$ Ang-Lee et al. identified increased potential for bleeding with ginkgo extracts and recommended discontinuation 36 hours before surgery. ${ }^{95}$ The American Society of Anesthesiologists recommends patients discontinue herbal medicines (including ginkgo) 2 weeks before elective surgery. ${ }^{96}$ Ginkgo is also a potent peripheral vasodilator, ${ }^{97}$ and long-term ingestion can potentiate the effect of antihypertensives with excessive reduction of blood pressure. Gingko is a weak inhibitor of CYP3A4 (Table 3) and should be used cautiously with drugs metabolized by this enzyme system. Other adverse ginkgo-drug interactions include risk of priapism when combined with antipsychotic drug risperidone, ${ }^{98}$ seizure with anticonvulsants (valproic acid or phenytoin), ${ }^{99}$ coma with antidepressant trazodone ${ }^{100}$ and virological failure with efavirenz, a non-nucleoside reverse transcriptase inhibitor. ${ }^{101}$ 
Table 3. Drugs affecting CYP3A4 enzymes*

\begin{tabular}{|c|c|}
\hline $\begin{array}{l}\text { Strong inhibitors } \\
\text { ( } \geq 5 \text {-fold } \uparrow \text { in AUC or }>80 \% \downarrow \text { in } C L)\end{array}$ & $\begin{array}{l}\text { Strong inducers } \\
(\geq 80 \% \downarrow \text { in AUC) }\end{array}$ \\
\hline $\begin{array}{l}\text { Boceprevir, clarithromycin, conivaptan, grapefruit juice }{ }^{\dagger} \text { indinavir, itraconazole, } \text { ketoconazole, lopinavir/ritonavir, nefazodone, nelfinavir, posaconazole, ritonavir, } \\
\text { saquinavir, telaprevir, telithromycin, voriconazole }\end{array}$ & $\begin{array}{l}\text { Carbamazepine, phenytoin, } \\
\text { rifampin, St. John's wort }{ }^{\S}\end{array}$ \\
\hline $\begin{array}{l}\text { Moderate inhibitors } \\
\text { ( } \geq 2 \text {-fold but }<5 \text {-fold } \uparrow \text { in AUC or } 50-80 \% \downarrow \text { in CL) }\end{array}$ & $\begin{array}{l}\text { Moderate inducers } \\
(50-80 \% \downarrow \text { in AUC) }\end{array}$ \\
\hline $\begin{array}{l}\text { Amprenavir, aprepitant, atazanavir, ciprofloxacin, darunavir/ritonavir, diltiazem, } \\
\text { erythromycin, fluconazole, fosamprenavir, grapefruit juice, }{ }^{\dagger} \text { imatinib, verapamil }\end{array}$ & $\begin{array}{r}\text { Bosentan, efavirenz, etravirine, } \\
\text { modafinil, nafcillin }\end{array}$ \\
\hline $\begin{array}{l}\text { Weak inhibitors } \\
(\geq 1.25 \text {-fold but }<2 \text {-fold } \uparrow \text { in AUC or } 20-50 \% \downarrow \text { in CL) }\end{array}$ & $\begin{array}{l}\text { Weak inducers } \\
(20-50 \% \downarrow \text { in AUC) }\end{array}$ \\
\hline $\begin{array}{l}\text { Alprazolam, amiodarone, amlodipine, atorvastatin, bicalutamide, cilostazol, } \\
\text { cimetidine, cyclosporine, fluoxetine, fluvoxamine, ginkgo, } \$ \text { isoniazid, nilotinib, } \\
\text { oral contraceptives, ranitidine, ranolazine, tipranavir/ritonavir, zileuton }\end{array}$ & $\begin{array}{r}\text { Amprenavir, aprepitant, armodafinil, } \\
\text { echinacea, }{ }^{\S} \text { pioglitazone, } \\
\text { prednisone, rufinamide }\end{array}$ \\
\hline
\end{tabular}

*Note that this is not an exhaustive list. Source: U.S. Food and Drug Administration (http://www.fda.gov/Drugs/

DevelopmentApprovalProcess/DevelopmentResources/DrugInteractionsLabeling/ucm093664.htm\#cypEnzyme).

tThe effect of grapefruit juice varies widely among brands and is concentration-, dose- and preparation-dependent. Studies have shown that it can be classified as a "strong CYP3A inhibitor" when a certain preparation was used (e.g. high dose, double strength) or as a "moderate CYP3A inhibitor" when another preparation was used (e.g. low dose, single strength).

¥The effect of St. John's wort varies widely and is preparation-dependent.

sHerbal product.

$A \cup C$, area under curve; CL, clearance.

\section{Milk Thistle}

Milk thistle (Silybum marianum) extract is a popular herbal product used for mushroom poisoning (Amanita phalloides), chemoprevention and hepatoprotection in the setting of hepatitis or cirrhosis. Silymarin is a flavonoid complex, extracted from the seeds of milk thistle, with active constituents silibinin, isosilybinin, silydianin, silychristin and other phenol compounds. Silymarin has strong antioxidant activity ${ }^{102}$ and exhibits antiviral, cytoprotective, ${ }^{103}$ anti-inflammatory, immunomodulatory, anticarcinogenic ${ }^{104}$ and antiapoptotic effects. Silymarin inhibits both phase I and phase II liver enzymes, but has limited effect on in vivo pharmacokinetics of several drugs ${ }^{105}$ despite inhibiting the activity of CYP and uridine 5'-diphosphoglucoronyltransferase enzymes and reducing P-glycoprotein transport. Metabolic interactions of milk thistle with substrates metabolized by CYP3A4 or CYP2C9 or transported by P-glycoprotein, especially drugs with a narrow therapeutic index such as anticoagulants or digoxin, cannot be excluded ${ }^{106,107}$ and should be monitored closely.

\section{Black Cohosh}

Black cohosh (Cimicifuga racemosa) is used as an herbal remedy for relief of symptoms of premenstrual tension, menopause and other gynecological disorders. The exact mechanism of action of black cohosh is unclear. Recent findings suggest some of the physiological effects of black cohosh may be due to compounds that bind and activate serotonin receptors. ${ }^{108}$ It also contains complex biological molecules, such as triterpene glycosides, which block osteoclastogenesis in vivo and in vitro, thereby reducing cytokine-induced bone loss (osteoporosis). ${ }^{109}$ A National Center of Complementary and Integrative Health (NCCIH)-funded study found black cohosh, whether used alone or with other botanicals, failed to relieve hot flashes and night sweats in postmenopausal women. ${ }^{110}$ In a Cochrane systematic review of 16 randomized controlled trials, recruiting a total of 2,027 perimenopausal or postmenopausal women, no significant difference between black cohosh and placebo in the frequency of hot flashes or in menopausal symptoms was found. ${ }^{11}$ 
The current evidence on the safety of black cohosh is inconclusive due to poor reporting. Davis et al. showed no increase in the incidence of primary breast cancer in black cohosh-treated transgenic mice, but increased lung metastasis of preexisting breast cancer. ${ }^{12}$ While uncommon, a few cases of black cohosh-related hepatotoxicity were reported. ${ }^{113}$ Although a 2011 metaanalysis refuted this concern, ${ }^{114}$ regulatory agencies in Australia, Canada and the European Union released statements regarding the "potential association" between black cohosh and hepatotoxicity. The United States Pharmacopeia advises that black cohosh products be labeled with a cautionary statement of hepatotoxicity. This is a change from its expert committee's 2002 decision, which required no such statement. ${ }^{115}$

\section{Echinacea}

Echinacea (Echinacea purpurea, Echinacea pallida and Echinacea angustifolia) is known mainly for its immunostimulant properties used for the prevention and treatment of common cold and influenza, but efficacy studies have yielded inconsistent results. ${ }^{116}$ Randomized, double-blind, placebo-controlled trials showed no beneficial effects of unrefined echinacea or echinacea capsules on symptoms of common cold or rhinovirus infection compared to placebo. ${ }^{117,118}$ Echinacea use has been reported to cause side effects such as nausea, dizziness and gastrointestinal upset. Echinacea inhibits hepatic enzymes CYP1A2 and CYP2C9. Echinacea has a complex effect on CYP3A4 activity, inhibiting intestinal CYP3A4 but increasing hepatic CYP3A4 activity (Table 3 ), ${ }^{119}$ therefore the effect on oral versus parenteral medications could be different. Thus, the effect of echinacea in the elderly using medications metabolized by CYP3A4 should be closely monitored or used with caution. ${ }^{120}$

Echinacea does not change the pharmacokinetics of digoxin, a P-glycoprotein substrate, ${ }^{121}$ nor does it alter the pharmacokinetics of chlorzoxazone (CYP2E1 probe), ${ }^{122}$ debrisoquine (CYP2D6 probe) $)^{122}$ or tolbutamide (CYP2C9 probe). ${ }^{119}$ In 12 healthy subjects, after a single dose of warfarin before and after taking echinacea for 14 days, the pharmacokinetics and pharmacodynamics of warfarin were not significantly altered. ${ }^{123}$ Liver toxicity with elevation of transaminases was reported in patients using echinacea, ${ }^{124}$ and caution should be used when combining it with other medications that can harm the liver. ${ }^{52,125}$ Echinacea may decrease the effects of cyclosporine and steroids because of the immunostimulant effect and complex effect on CYP3A4 activity, ${ }^{120,125}$ therefore transplant patients should be advised against using this herb.

\section{St. John's Wort}

St. John's wort or St. Joan's wort (Hypericum perforatum), a perennial herb first used as a supplement by the ancient Greeks, is popular in Europe and the United States. It is used as a folk remedy for depression, anxiety, mental health conditions and sleep disturbances. Studies measuring the effectiveness of St. John's wort in treating depression have yielded conflicting results. A large 2002 study showed the herb to be no more effective than placebo in treating moderately severe major depression. ${ }^{126}$ Linde et al.'s Cochrane analysis ${ }^{127}$ of St. John's wort for major depression reviewed 29 randomized, double-blind studies comprising 5,489 people and concluded that hypericum extracts were more effective than placebo and as effective as standard antidepressants with a lesser toxicity profile for major depressive episodes. However, the authors noted studies conducted in German-speaking countries were more favorable to hypericum than others including the United States. They recommended further investigating the reasons for these differences.

Due to its potential for drug interactions St. John's wort is not a benign supplement, and its current use as an over-the-counter medicine for depression is not endorsed by the FDA. Its active constituent hyperforin is a well-known activator of the pregnane $\mathrm{X}$ receptor, ${ }^{128}$ which results in enhanced expression of the drug efflux transporter ABCB1 (P-glycoprotein) ${ }^{129}$ and induction of CYP3A4 (Table 3), an enzyme involved in metabolism of the majority of prescription medications used in cardiovascular practice. ${ }^{130}$ Thus, potentially serious adverse reactions can occur from coadministration with drugs metabolized through CYP3A4 or transported by P-glycoprotein. Hypotension and delayed emergence from anesthesia were associated with prior use of St. John's wort. ${ }^{131}$ In HIV patients, it can decrease plasma levels of indinavir, resulting in failure of antiretroviral therapy. ${ }^{129}$ It can reduce drug levels of ethinylestradiol, ${ }^{132}$ and women taking St. John's wort with oral contraceptives could experience an unplanned pregnancy or increased breakthrough bleeding due to decreased efficacy. ${ }^{133}$ It can increase docetaxel's plasma clearance, reducing its efficacy and peak plasma concentration, thus causing 
undertreatment of cancer patients. ${ }^{134}$ It causes a nearly $50 \%$ decrease in cyclosporine levels in organ transplant recipients, ${ }^{135}$ and cases of acute transplant rejection have been reported. ${ }^{135-137}$ The consequent potential for transplant rejection is a life-threatening effect and justifies abolishing use of St. John's wort in this patient population. ${ }^{138}$ Reduced levels of digoxin also have been reported. ${ }^{139}$ St. John's wort can alter anticoagulation properties of warfarin resulting in unstable INR values, ${ }^{140}$ and bleeding complications were reported in elderly taking warfarin ${ }^{141}$ (Table 2 and Online Supplemental Appendix 1). It can cause hypertensive crisis with foods rich in tyramine. ${ }^{142}$ Additionally, use of St. John's wort is associated with the induction of mania or hypomania in patients suffering with bipolar disorder, ${ }^{143}$ and it has been implicated with causing reversible photosensitivity and erythematous skin lesions after sun exposure. ${ }^{144}$

\section{Ginseng}

American ginseng (Panax quinquefolius) and Asian ginseng (Panax ginseng) belong to the genus Panax in which the main active constituents are steroidal saponins called ginsenosides, ${ }^{145}$ whereas Siberian ginseng (Eleutherococcus senticosus) is in the same family but not genus, with eleutherosides as the active component. These are commonly used herbs worldwide, consumed in various forms including as tea and other beverages. They are used mainly for beneficial effect in stress reduction, memory enhancement, attention deficit hyperactivity disorder, sexual dysfunction and alleviation of menopausal symptoms. They also have shown immunomodulatory, antidiabetic, anti-aging, antifatigue and anticancer properties. The content of ginsenosides in the Asian ginseng depends on the raw (white) root versus steamed (red) ginseng root. Most ginsenosides and eleutherosides were reported to have an inhibitory effect on enzymes CYP1A2, CYP2C9, CYP2C19, CYP2D6 and CYP3A4. ${ }^{146}$ One case of imatinib-induced hepatotoxicity after concurrent ginseng ingestion in a patient with chronic myelogenous leukemia was reported, which resolved after short course of corticosteroids and ginseng withdrawal. ${ }^{147}$ Another case reported similar findings with concomitant use of antiretroviral drug raltegravir and ginseng in an HIV-positive patient with long-term hepatitis C. ${ }^{148}$ Thus, ginseng should be used with caution with other CYP3A4-metabolized drugs and in patients with preexisting liver conditions. Surprisingly, Gurley et al. noted ginseng did not affect other CYP enzymes except for slight inhibition of CYP2D6. ${ }^{149}$
Ginsenosides can inhibit platelet aggregation and thromboxane formation in vitro, ${ }^{150}$ prolong activated partial thromboplastin time and thrombin time in rats, ${ }^{151}$ and cause irreversible human platelet inhibition by panaxynol, a constituent of ginseng. ${ }^{152}$ Decreased anticoagulant effects of warfarin in a patient whose therapy had been stable previously ${ }^{153}$ and thrombosis with a subtherapeutic INR were reported. ${ }^{154}$ American ginseng also was shown to reduce warfarin effect in healthy volunteers. ${ }^{155}$ In contrast, other ginseng species, including Asian ginseng ${ }^{156}$ and Korean red ginseng, ${ }^{157}$ did not affect warfarin's anticoagulant effect. In 12 healthy subjects, ginseng treatment for 2 weeks did not affect either the pharmacokinetics or pharmacodynamics of a single 25-mg dose of warfarin. ${ }^{140}$ Long-term effects of ginseng in elderly with comorbidities have not been systematically assessed. Because of the potential for platelet inhibition in humans, ginseng use should be discontinued in patients at least 1 week before surgery. ${ }^{95}$

There is also conflicting evidence of estrogenic properties of ginsenosides. Human studies in pregnancy and lactation are lacking, but there is in vitro evidence of teratogenicity in animal embryos with ginsenoside use. Thus, caution should be exercised with ginseng's use during pregnancy and lactation and should be avoided if possible. Ginseng may lower blood sugar levels, and this effect may be greater in patients with diabetes than in nondiabetic individuals. Hypoglycemia has been described with concomitant use of ginseng with oral hypoglycemic agents, ${ }^{158}$ and its use has been reported to reduce postprandial increment of glucose in nondiabetics. ${ }^{159}$ Caution is advised when using it with antidiabetic medicines or supplements that might lower blood sugar (devil's claw, ginger, fenugreek, gum and guar), and blood glucose levels may require closer monitoring and dose adjustments. Ginseng may increase cardiac repolarization and QTc interval $^{160}$ as well as proarrhythmic risk by additional increase in the bioavailability of antiarrhythmic agents due to reduced metabolism. ${ }^{161}$ Siberian ginseng was reported to reproducibly elevate digoxin concentrations, which normalized after discontinuation and increased after resumption of ginseng. ${ }^{162}$ Ginsenosides, which include more than 20 saponin glycosides with a nucleus similar in structure to steroid hormones, ${ }^{163}$ can cause mastalgia, ${ }^{164}$ functionally abnormal vaginal bleeding ${ }^{165}$ and gynecomastia in males. Coingestion of American ginseng with antidepressants like phenelzine can cause side effects like nervousness, anxiousness, headache 
and insomnia. ${ }^{166}$ Hypertension has been reported with chronic ginseng ingestion, with normalization of blood pressure after ginseng discontinuation. ${ }^{167}$

\section{Grapefruit Juice}

Grapefruit (Citrus paradisi) juice is commonly used for its medicinal effect in regulating glucose levels in diabetics, to prevent cancer and in lowering serum cholesterol levels in cardiovascular diseases. Active ingredients within grapefruit juice (furanocoumarins and the flavonoids naringenin and bergamottin) have an inhibitory effect on P-glycoprotein, organic anionic transporting polypeptide and CYP3A4 enzymatic activity in intestinal enterocytes, mostly affecting orally administered drugs. This can lead to elevations of the serum concentrations of drugs transported by P-glycoprotein or metabolized by CYP3A4 substrates (Table 3) and cause adverse effects. Even a single exposure to one glass of the grapefruit juice can produce clinically significant interaction, and with the half-life of CYP3A4 being $>8$ hours, its reversal inhibition by grapefruit increases the bioavailability and blood levels of drugs metabolized by this enzyme (Table 3) up to 72 hours. ${ }^{168,169}$ Therefore, repeated juice intake can result in adverse effects even if not taken concomitantly with drugs. This effect is present whether grapefruit is taken as a whole fruit or in juice form, causing clinically relevant increase in blood concentration of affected drugs that can result in adverse effects. ${ }^{170}$ Some examples include exaggerated antihypertensive response with calcium channel blockers (felodipine), ${ }^{171}$ increased risk of rhabdomyolysis and hepatotoxicity with statins, ${ }^{168}$ hypoglycemia with antidiabetics (repaglinide), increased steady-state concentration of cyclosporine, potentiation of toxicity with antiarrhythmics with QT prolongation and torsades de pointes, ${ }^{172}$ and augmentation of antiplatelet activity of cilostazol leading to pupura. ${ }^{173}$

There also are case reports of elevated INR and hematoma with grapefruit juice ingestion in patients previously stabilized on warfarin. ${ }^{174}$ Therefore, drug interactions with grapefruit juice are a concern, especially in situations when the magnitude of interaction is large, in drugs with a narrow therapeutic index and in the elderly with multiple comorbidities and polypharmaceutical regimens. Its use in such populations should be limited and the potential for adverse grapefruit and drug interaction should be discussed with the elderly taking drugs metabolized through CYP3A (Table 3) or transported through P-glycoprotein to avoid any potential adverse effect.

\section{Federal Regulation of Herbal Supplements}

Herbal supplements are "medicinal" products of plant origin that are not officially recognized as drugs nor intended for use as conventional foods, but are considered part of treatment modalities in integrative medicine. Unlike drug products that must be proved safe and effective before marketing, herbal or dietary supplements do not need prior FDA authorization before being marketed except for "new dietary ingredients" marketed after October 15, 1994, which only require demonstration of safety and not efficacy by submitting a premarket notification 75 days prior to the launch of the new product. However, the FDA does require manufacturers to register with its agency.

The U.S. Dietary Supplement Health and Education Act of 1994 defines and regulates dietary supplements. ${ }^{175}$ Under the act, supplements are effectively regulated by the FDA for Good Manufacturing Practices under 21 CFR Part 111. ${ }^{176}$ The current Good Manufacturing Practices (cGMP) final rule ${ }^{177}$ ensures consistency by requiring information about manufacturing, packing, labeling, identity, quality, strength, purity and composition in the manufacture of dietary supplements. However, without validated analytical standards and methods to detect the active ingredients of the vast majority of herbal supplements, it is difficult for the FDA to detect potency or dosing requirements for these herbal products. The cGMP final rule requires that manufacturers, not the FDA, determine the quality specifications for their products, and companies that want to use less stringent specifications can do so without penalty. ${ }^{178}$

Manufacturers may make three types of claims for their dietary supplement products: health claims, structure/function claims and nutrient content claims. These claims are not endorsed by the FDA, and the manufacturer is solely responsible for ensuring the accuracy and truthfulness of these claims. Thus, by law, if a dietary supplement makes a claim, it must state a "disclaimer" that the FDA has not evaluated the claim. The disclaimer also must state that this product is not intended to "diagnose, treat, cure or prevent any disease," because only a drug can legally make such a claim. Manufacturers, packagers and distributors of 
dietary supplements are required to report any serious adverse events to the FDA within 15 business days after being notified (i.e. consumer complaints), but they are not required to do any active surveillance and reporting on their own. They also need to provide any additional medical information they obtain within a year of the adverse event report.

Consumers and other health care providers are encouraged to report similar adverse events to the FDA. The FDA has intervened by identifying harmful dietary supplements or potential contamination, but while FDA's curbing measures have had some impact, it has not been enough to restrict the access of hazardous botanicals to general consumers when manufacturers can simply introduce new similar formulations. ${ }^{179}$ With the limited resources available to the FDA, and presence of 1,800 manufacturers and more than 75,000 products in the supplement market, ${ }^{178}$ enforcement of existing laws is difficult. ${ }^{180}$ The FDA cannot fully accomplish its mission of consumer protection without increased resources and regulations on the industry.

\section{Limitations of Scientific Evidence on Efficacy and Safety}

Most of the scientific knowledge on herbal remedies and herb-drug interactions comes from in vitro studies, animal studies and case reports; there is a lack of validated controlled clinical trials. Information about pharmacokinetics, pharmacodynamics, efficacy and safety of herbal products in the elderly population with cardiovascular diseases, ${ }^{181}$ who also have multiple comorbidities and take different medicines, is particularly limited. ${ }^{182}$ Lack of safety data for cardiovascular disease patients is a recurring phenomenon in herbal medicine, with no rigorous attention given to adverse events or interactions with prescription drugs. ${ }^{13}$ Even when data are available for other populations, typically healthy volunteers or low-risk patients without comorbid conditions, findings are often questionable because of a lack of consistency in research methods, small number of subjects, absence of placebo groups, lack of standardization of supplements and absence of data on herb-drug interactions. Thus, findings for specific herbal products are of limited usefulness for making decisions about efficacy or safety. The dramatic increase of dietary supplement sales in the last two decades has unmasked several herbal adverse effects and life-threatening herb-drug interactions as discussed in this review, particularly with the use of St. John's wort. The elderly are particularly susceptible to herb-mediated changes to CYP activity and should be properly instructed to avoid supplements that can increase adverse efects. ${ }^{149,183}$ For example one study reported ginseng inhibited CYP2D6 in elderly but not younger subjects. ${ }^{184}$

Most of the information about drug-herb interactions comes from clinical practice, but a systematic assessment of such interactions by collecting data from clinical studies may provide additional insights. In addition, the system for reporting adverse effects needs to be closely followed by consumers, health care providers and manufacturers to report adverse interactions as emphasized by the Institute of Medicine. ${ }^{185}$

\section{Inadequate Quality Control Measures}

Herbal and dietary supplement manufacturers in the United States include a blanket warning on labels rather than specifying adverse effects and potential interactions. ${ }^{133,186,187}$ Additionally, herbal products may be contaminated with other substances, contain attenuated quantity or quality of active ingredients ${ }^{188}$ or many not contain the intended ingredient at all, causing variations in their side effect profiles. ${ }^{189}$ A 2013 study of 44 popular supplements sold by 12 companies showed most of the herbal products tested were of poor quality, often diluted or replaced by cheap fillers like soybean, wheat and rice. ${ }^{190}$ A recent investigation by the New York Attorney General's office into store-brand supplements at four national retailers showed all but five of the 24 products tested to be either contaminated or replaced by another plant product. ${ }^{191}$

Despite FDA guidelines mandating manufacturers to avoid contamination, supplements repeatedly have been reported to contain adulterant compounds, including other herbs, heavy metals, ${ }^{28,192}$ anabolic steroids ${ }^{22}$ or prescription drugs ${ }^{193}$ as well as contaminant microbials, ${ }^{27}$ pesticides and other compounds ${ }^{26}$ that put unsuspecting consumers at risk of adverse side effects and herb-drug interactions. Several cases of potentially life-threatening hepatotoxicity (leading to liver transplantation in some) attributed to Herbalife ${ }^{\circledR}$ products (Los Angeles, CA) marketed for promoting energy, fitness and weight control were recently documented. ${ }^{194}$ In an analysis of 20 herbal/dietary supplements marketed as natural slimming products, eight formulations contained sibutramine, five had sibutramine with phenolphthalein and one was adulterated with 
synephrine. ${ }^{21}$ Sibutramine has a potential for abuse or addiction and elevates blood pressure and heart rate, posing significant risk to patients with heart disease, heart failure, arrhythmias or stroke, ${ }^{195}$ while phenolphthalein is known to have carcinogenic properties. In June 2011, two New Jersey dietary supplement companies were forced to shut down all manufacturing and distribution following FDA investigation into violations of misbranding food labels, selling products containing a major food allergen and having unhygienic conditions; a dead rodent cut in half along with rodent excreta and pellets were found on a blender motor platform, and bags of raw ingredients were gnawed through by rodents and covered with rodent urine and feces. ${ }^{196}$

No package inserts for herbal supplements describing potential adverse events or drug interactions are required, and patients have no way of distinguishing safe from potentially harmful supplements. Direct-to-consumer advertisement featuring extravagant, unsubstantiated and dubious health claims by the supplement industry ${ }^{197}$ continues despite regulatory guidelines. The Federal Trade Commission provides oversight and guidance but relies on advertisement surveillance for enforcement of its guidelines rather than approval before use. Thus, despite levying millions of dollars of fines yearly, misleading marketing campaigns continue to thrive. ${ }^{198}$

\section{Underreporting of Adverse Herb Reactions and Herb-Drug Interactions}

An FDA-commissioned study estimated receiving less than $1 \%$ of all adverse events associated with dietary supplements. ${ }^{199}$ Many herb-related adverse events are underreported by patients or clinical practioners, ${ }^{200}$ probably for a multitude of reasons. Consumers perceive herbal products as "natural remedies" carrying minimal to no risk, ${ }^{201}$ and are thus unable to correlate any adverse effects and more likely to blame prescription medicines when encountering a side effect. Most complementary medicine users fail to disclose herbal product use to their physicians. ${ }^{202}$ Consumers may lack direction on how to file a complaint or may assume it is the role of the health care provider once informing them of an adverse event. Health providers have limited training on herbal adverse effects, toxicities and herb-drug interactions, ${ }^{203}$ and may underrecognize their occurrence. A prospective study looking into web-based questionnaires administered to health care providers noted that approximately $73 \%$ of physician respondents did not know how or where to report adverse events related to dietary supplements. ${ }^{204}$ The Dietary Supplements Information Expert Committee has recommended enhancing data collection approaches, improving coordination of adverse event-related surveillance programs, strengthening education programs for public and health care sectors and conducting further research into safety of dietary supplements. ${ }^{205}$ Reports of suspected or documented adverse events may be submitted voluntarily to the FDA's MedWatch program ${ }^{206}$ or other organizations such as a poison control center.

\section{Public Misperception of Benefits of Herbal Supplementation}

The public seems to believe that dietary supplements, like pharmaceuticals, undergo scrutiny and rigorous research before marketing. According to a nationwide interactive poll of 1,010 respondents, $59 \%$ of the respondents believed the supplements were approved by a government agency before being sold, $68 \%$ believed that listing potential side effects on labels was a requirement and $55 \%$ believed that supplement manufacturers were required to make scientific evidence-backed safety claims. ${ }^{207}$ Similarly, the PEW Internet and American Life Project reported $52 \%$ of users to have visited health sites believed "almost all" or "most" health information on the Internet is credible. ${ }^{208}$ While some media sources provide a wealth of accurate information, others contain false, unsubstantiated information or even conflicting statements. For example, in a study of Internet marketing of herbal products ${ }^{197}$ at least $81 \%$ of websites were found to make one or more health claims, with more than $50 \%$ claiming to treat, prevent, diagnose or cure specific diseases despite regulations barring such statements. Another study investigating 12 weight-loss supplements sold online identified eight ingredients with reported lifethreatening cardiac adverse effects or death. ${ }^{209}$ Warning about potential adverse effects did not appear on the web pages. One product's list of ingredients included ma huang (Chinese ephedra), even though marketing of ephedracontaining products is banned in the United States. The popular belief that natural supplements confer health benefits ${ }^{210}$ without potential for harm ${ }^{211}$ makes consumers vulnerable to making choices that could be deleterious.

\section{Knowledge Barriers Between Patients and Providers Regarding Herb-Drug Interactions}

Many herbal supplements contain active ingredients that have strong biological effects and can make them unsafe in certain situations, especially when consumed 
in large amounts or taken with drugs that can alter their pharmacokinetic and pharmacodynamics parameters. Despite increased educational initiatives and the large body of literature on herbal remedies, there remains a considerable knowledge gap on herb-related safety issues among both health care providers ${ }^{212}$ and health store employees ${ }^{213}$ who are usually the first point of contact for consumers interested in buying herbal remedies. This lack of knowledge exchange can result in distribution of inconsistent information that can heighten confusion and spread false messages, thus further complicating issues. Physicians are advised to be aware of potential therapeutic benefits of complementary and alternative medicinal agents while at the same time wary of their unwanted risks, toxicities and potential interactions. Better recognition of herb profiles will allow physicians to identify herb-drug interferences, antagonisms and synergies and assist in formulating better goal-driven individualized health care plans.

Initiatives like the Dietary Supplement Verification Program from U.S. Pharmacopeia can ensure that products are labeled correctly and devoid of contaminants. It is also important for health care providers to develop good communication with their patients and create a comfortable environment for discussing herbs and other supplements. Consumers are encouraged to consult with their medical providers when concomitantly using nutraceuticals with prescription drugs. It is prudent to work with preparations manufactured by companies that adhere to Good Manufacturing Practices pharmaceutical standards. However, many of these products are not readily available to the public over the counter. Without the same oversight for herbal products that is required for allopathic medicine, the public risks self-medicating with substances that are potentially ineffective, deleterious or both, leading to harmful consequences.

\section{Conclusions}

Most medications, herbal preparations and nutraceuticals have notable effects on biochemical pathways and can influence wound healing, metabolic processes, coagulation and cardiovascular function. They also can interact with other prescribed drugs. A large portion of the data available regarding the effects of herbal medicines is anecdotal and lacks proper evidence regarding safety in the elderly with multiple comorbidities. Quality control standards are highly variable and marketing of many products misleading or potentially harmful when used by the vulnerable population taking multiple medicines.

Public and health practitioners need to be reminded that herbal supplements are bioactive compounds and could have adverse effects when combined with medications whose effectiveness and safety can be altered by natural products such as St. John's wort or grapefruit juice. General guidelines or expert opinion-based recommendations have been provided in peer-reviewed journals, but national guidelines are needed. The National Center for Complementary and Integrative Health provides information about commonly used herbs and their potential for drug interactions. Major academic centers (e.g. Mayo Clinic, Memorial Sloan-Kettering Hospital and University of Maryland) also provide this information, and links to these sites are provided in Online Supplemental Appendix 2.

\section{Patient-Friendly Recap}

- Herbal products are sold as dietary supplements and not subject to the same regulatory standards as pharmacological drugs.

- The FDA previews "dietary ingredients" for safety, but not for effectiveness.

- Elderly patients with comorbidities using multiple medications and dietary supplements are at increased risk of adverse interactions.

- Unlike drugs, supplements are not intended to treat, diagnose, prevent or cure diseases, and such claims need to be proven scientifically before accepted by the public or health care providers.

- Products sold as "natural" are not always safe. Always remember - safety first.

\section{Funding Sources}

Dr. Jahangir is supported by a grant from the National Heart, Lung, and Blood Institute (R01 HL101240) and intramural research funding from Aurora Health Care. The content in this article is solely the responsibility of the authors and does not necessarily represent the official views of the NHLBI or National Institutes of Health.

\section{Conflicts of Interest}

None. 


\section{References}

1. Miller KL, Liebowitz RS, Newby LK. Complementary and alternative medicine in cardiovascular disease: a review of biologically based approaches. Am Heart J. 2004;147:401-11. CrossRef

2. Yeh GY, Davis RB, Phillips RS. Use of complementary therapies in patients with cardiovascular disease. Am J Cardiol. 2006;98:673-80. CrossRef

3. Eisenberg DM, Davis RB, Ettner SL, et al. Trends in alternative medicine use in the United States, 1990-1997: results of a follow-up national survey. JAMA. 1998;280: 1569-75. CrossRef

4. Nahin RL, Barnes PM, Stussman BJ, Bloom B. Costs of complementary and alternative medicine (CAM) and frequency of visits to CAM practitioners: United States, 2007. Natl Health Stat Report. 2009;(18):1-14.

5. Peregoy JA, Clarke TC, Jones LI, Stussman BJ, Nahin RL. Regional variation in use of complementary health approaches by U.S. adults. NCHS Data Brief. 2014;(146):1-8.

6. American Botanical Council. Herbal dietary supplement retail sales up 7.9\% in 2013 (Sept. 3, 2014). http://cms. herbalgram.org/press/2014/2013_Herb_Market_Report.html $? \mathrm{ts}=1436473622 \&$ signature $=9$ feba666bd6963 $18 \mathrm{fedbcbc}$ 61c8180f1. Accessed July 23, 2015.

7. Lindstrom A, Ooyen C, Lynch ME, Blumenthal M. Herb supplement sales increase 5.5\% in 2012: herbal supplement sales rise for 9 th consecutive year; turmeric sales jump $40 \%$ in natural channel (available online at http://cms.herbalgram. org/herbalgram/issue99/hg99-mktrpt.html). HerbalGram. 2013;(99):60-5.

8. Daniells S. Herbal supplement sales to hit $\$ 93.15$ billion by 2015: report (Jan. 13, 2011). http://www.nutraingredients-usa. com/Markets/Herbal-supplement-sales-to-hit-93.15-billionby-2015-Report. Accessed July 23, 2015.

9. Baum C, Kennedy DL, Forbes MB, Jones JK. Drug use in the United States in 1981. JAMA. 1984;251:1293-7. CrossRef

10. Nahin RL, Pecha M, Welmerink DB, et al. Concomitant use of prescription drugs and dietary supplements in ambulatory elderly people. J Am Geriatr Soc. 2009;57:1197-205. CrossRef

11. Samaras D, Samaras N, Lang PO, Genton L, Frangos E, Pichard C. Effects of widely used drugs on micronutrients: a story rarely told. Nutrition. 2013;29:605-10. CrossRef

12. Tachjian A, Maria V, Jahangir A. Use of herbal products and potential interactions in patients with cardiovascular diseases. J Am Coll Cardiol. 2010;55:515-25. CrossRef

13. Jahangir A, Viqar M, Tachjian A. Reply to: Use of herbal products and potential interactions in patients with cardiovascular diseases. J Am Coll Cardiol. 2010;56:905-9. $\underline{\text { CrossRef }}$

14. Carlson JE. Perils of polypharmacy: 10 steps to prudent prescribing. Geriatrics. 1996;51:26-30, 35.

15. Mirza M, Strunets A, Shen WK, Jahangir A. Mechanisms of arrhythmias and conduction disorders in older adults. Clin Geriatr Med. 2012;28:555-73. CrossRef

16. Thomson P, Jones J, Evans JM, Leslie SL. Factors influencing the use of complementary and alternative medicine and whether patients inform their primary care physician. Complement Ther Med. 2012;20:45-53. CrossRef

17. AARP and National Center for Complementary and Alternative Medicine Survery Report. Complementary and alternative medicine: what people aged 50 and older discuss with their health care providers. https://nccih.nih.gov/sites/ nccam.nih.gov/files/news/camstats/2010/NCCAM_aarp_ survey.pdf. Accessed September 20, 2015.

18. National Center for Complementary and Alternative Medicine. Time to talk about CAM: health care providers and patients need to ask and tell (NIH News, June 6, 2008). http:// www.nih.gov/news/health/jun2008/nccam-06.htm. Accessed September 20, 2015.

19. MedLine Plus. Ginseng, Panax. http://www.nlm.nih.gov/ medlineplus/druginfo/natural/patient-ginseng.html. Accessed July 23, 2015.

20. Johnson JC. General concepts of geriatric medicine. Clin Podiatr Med Surg. 1993;10:23-33.

21. Vaysse J, Balayssac S, Gilard V, Desoubdzanne D, MaletMartino M, Martino R. Analysis of adulterated herbal medicines and dietary supplements marketed for weight loss by DOSY 1H-NMR. Food Addit Contam Part A Chem Anal Control Expo Risk Assess. 2010;27:903-16. CrossRef

22. Geyer H, Parr MK, Koehler K, Mareck U, Schänzer W, Thevis M. Nutritional supplements cross-contaminated and faked with doping substances. J Mass Spectrom. 2008;43:892-902. CrossRef

23. U.S. Food and Drug Administration. Steam dietary supplement (safety alert; Aug. 24, 2009). http:// www.fda.gov/Safety/MedWatch/SafetyInformation/ SafetyAlertsforHumanMedicalProducts/ucm 174339.htm. Accessed September 20, 2015.

24. U.S. Food and Drug Administration. FDA warns consumers to avoid red yeast rice products promoted on internet as treatments for high cholesterol products found to contain unauthorized drug (news release; Aug. 9, 2007). http://www. fda.gov/NewsEvents/Newsroom/PressAnnouncements/2007/ ucm108962.htm. Accessed May 15, 2010.

25. Navarro VJ. Herbal and dietary supplement hepatotoxicity. Semin Liver Dis. 2009;29:373-82. CrossRef

26. Dara L, Hewett J, Lim JK. Hydroxycut hepatotoxicity: a case series and review of liver toxicity from herbal weight loss supplements. World J Gastroenterol. 2008;14:6999-7004. CrossRef

27. Stickel F, Droz S, Patsenker E, Bögli-Stuber K, Aebi B, Leib SL. Severe hepatotoxicity following ingestion of Herbalife nutritional supplements contaminated with Bacillus subtilis. J Hepatol. 2009;50:111-7. CrossRef

28. Saper RB, Phillips RS, Sehgal A, et al. Lead, mercury, and arsenic in US- and Indian-manufactured Ayurvedic medicines sold via the Internet. JAMA. 2008;300:915-23. CrossRef

29. Hanley MJ, Cancalon P, Widmer WW, Greenblatt DJ. The effect of grapefruit juice on drug disposition. Expert Opin Drug Metab Toxicol. 2011;7:267-86. CrossRef

30. Custodio JM, Wu CY, Benet LZ. Predicting drug disposition, absorption/elimination/transporter interplay and the role of food on drug absorption. Adv Drug Deliv Rev. 2008;60:717-33. CrossRef

31. Fernández-San-Martin MI, Masa-Font R, Palacios-Soler L, Sancho-Gömez P, Calbö-Caldentey C, Flores-Mateo G. Effectiveness of Valerian on insomnia: a meta-analysis of randomized placebo-controlled trials. Sleep Med. 2010;11:505-11. CrossRef

32. Shi Y, Dong JW, Zhao JH, Tang LN, Zhang JJ. Herbal insomnia medications that target GABAergic systems: a review of the psychopharmacological evidence. Curr Neuropharmacol. 2014;12:289-302. CrossRef 
33. Jepson RG, Williams G, Craig JC. Cranberries for preventing urinary tract infections. Cochrane Database Syst Rev. 2012;10:CD001321. CrossRef

34. Griffiths AP, Beddall A, Pegler S. Fatal haemopericardium and gastrointestinal haemorrhage due to possible interaction of cranberry juice with warfarin. $J R$ Soc Promot Health. 2008;128:324-6. CrossRef

35. Rindone JP, Murphy TW. Warfarin-cranberry juice interaction resulting in profound hypoprothrombinemia and bleeding. Am J Ther. 2006;13:283-4. CrossRef

36. Mohammed Abdul MI, Jiang X, Williams KM, et al. Pharmacodynamic interaction of warfarin with cranberry but not with garlic in healthy subjects. $\mathrm{Br} J$ Pharmacol. 2008;154:1691-700. CrossRef

37. Greenblatt DJ, von Moltke LL, Perloff ES, Luo Y, Harmatz JS, Zinny MA. Interaction of flurbiprofen with cranberry juice, grape juice, tea, and fluconazole: in vitro and clinical studies. Clin Pharmacol Ther. 2006;79:125-33. CrossRef

38. Lilja JJ, Backman JT, Neuvonen PJ. Effects of daily ingestion of cranberry juice on the pharmacokinetics of warfarin, tizanidine, and midazolam--probes of CYP2C9, CYP1A2, and CYP3A4. Clin Pharmacol Ther. 2007;81:833-9. CrossRef

39. Ried K, Frank OR, Stocks NP. Aged garlic extract reduces blood pressure in hypertensives: a dose-response trial. Eur $J$ Clin Nutr. 2013;67:64-70. CrossRef

40. Ashraf R, Khan RA, Ashraf I. Garlic (Allium sativum) supplementation with standard antidiabetic agent provides better diabetic control in type 2 diabetes patients. PakJ Pharm Sci. 2011;24:565-70.

41. Aslam M, Stockley IH. Interaction between curry ingredient (karela) and drug (chlorpropamide). Lancet. 1979;1:607.

42. Laroche M, Choudhri S, Gallicano K, et al. Severe gastrointestinal toxicity with concomitant ingestion of ritonavir and garlic. (abstr.) Can J Infect Dis. 1998;9 Suppl A:471P.

43. Bordia A, Verma SK, Srivastava KC. Effect of garlic (Allium sativum) on blood lipids, blood sugar, fibrinogen and fibrinolytic activity in patients with coronary artery disease. Prostaglandins Leukot Essent Fatty Acids. 1998;58:257-63. CrossRef

44. Macan H, Uykimpang R, Alconcel M, et al. Aged garlic extract may be safe for patients on warfarin therapy. $J$ Nutr. 2006;136:793S-795S.

45. Banerjee SK, Maulik SK. Effect of garlic on cardiovascular disorders: a review. Nutr J. 2002;1:4. CrossRef

46. Rahman K, Billington D. Dietary supplementation with aged garlic extract inhibits ADP-induced platelet aggregation in humans. J Nutr. 2000;130:2662-5.

47. Evans V. Herbs and the brain: friend or foe? The effects of ginkgo and garlic on warfarin use. J Neurosci Nurs. 2000;32:229-32. CrossRef

48. German K, Kumar U, Blackford HN. Garlic and the risk of TURP bleeding. Br J Urol. 1995;76:518. CrossRef

49. Fedder SL. Spinal epidural hematoma and garlic ingestion. Neurosurgery. 1990;27:659. CrossRef

50. Di Silverio F, D'Eramo G, Lubrano C, et al. Evidence that Serenoa repens extract displays an antiestrogenic activity in prostatic tissue of benign prostatic hypertrophy patients. Eur Urol. 1992;21:309-14.

51. Ernst E. The risk-benefit profile of commonly used herbal therapies: ginkgo, St. John's wort, ginseng, echinacea, saw palmetto, and kava. Ann Intern Med. 2002;136:42-53. CrossRef

52. Miller LG. Herbal medicinals: selected clinical considerations focusing on known or potential drug-herb interactions. Arch Int Med. 1998;158:2200-11. CrossRef

53. Wilt T, Ishani A, Stark G, MacDonald R, Mulrow C, Lau J. Serenoa repens for benign prostatic hyperplasia. Cochrane Database Syst Rev. 2000;(2):CD001423. CrossRef

54. Bent S, Kane C, Shinohara K, et al. Saw palmetto for benign prostatic hyperplasia. $N$ Engl J Med. 2006;354:557-66. CrossRef

55. Tacklind J, Macdonald R, Rutks I, Stanke JU, Wilt TJ. Serenoa repens for benign prostatic hyperplasia. Cochrane Database Syst Rev. 2012;12:CD001423. CrossRef

56. Barry MJ, Meleth S, Lee JY, et al. Effect of increasing doses of saw palmetto extract on lower urinary tract symptoms: a randomized trial. JAMA. 2011;306:1344-51. CrossRef

57. Braeckman J. The extract of Serenoa repens in the treatment of benign prostatic hyperplasia: a multicenter open study. Curr Therap Res. 1994;55:776-85. CrossRef

58. Plosker GL, Brogden RN. Serenoa repens (Permixon). A review of its pharmacology and therapeutic efficacy in benign prostatic hyperplasia. Drugs Aging. 1996;9:379-95. CrossRef

59. Cheema P, El-Mefty O, Jazieh AR. Intraoperative haemorrhage associated with the use of extract of Saw Palmetto herb: a case report and review of literature. J Intern Med. 2001;250:167-9. CrossRef

60. Bressler R. Herb-drug interactions. Interactions between saw palmetto and prescription medications. Geriatrics. 2005;60:32, 34 .

61. Jibrin I, Erinle A, Saidi A, Aliyu ZY. Saw palmetto-induced pancreatitis. South Med J. 2006;99:611-2. CrossRef

62. Hamid S, Rojter S, Vierling J. Protracted cholestatic hepatitis after the use of prostata. Ann Intern Med. 1997;127:169-70. CrossRef

63. Yale SH, Glurich I. Analysis of the inhibitory potential of Ginkgo biloba, Echinacea purpurea, and Serenoa repens on the metabolic activity of cytochrome P450 3A4, 2D6, and 2C9. J Altern Complement Med. 2005;11:433-9. CrossRef

64. Gurley BJ, Gardner SF, Hubbard MA, et al. In vivo assessment of botanical supplementation on human cytochrome P450 phenotypes: Citrus aurantium, Echinacea purpurea, milk thistle, and saw palmetto. Clin Pharmacol Ther. 2004;76:428-40. CrossRef

65. Yue QY, Jansson K. Herbal drug curbicin and anticoagulant effect with and without warfarin: possibly related to the vitamin E component. J Am Geriatr Soc. 2001;49:838. CrossRef

66. Rossouw JE, Anderson GL, Prentice RL, et al. Risks and benefits of estrogen plus progestin in healthy postmenopausal women: principal results From the Women's Health Initiative randomized controlled trial. JAMA. 2002;288:321-33. CrossRef

67. Piersen CE. Phytoestrogens in botanical dietary supplements: implications for cancer. Integr Cancer Ther. 2003;2:120-38. CrossRef

68. Howes LG, Howes JB, Knight DC. Isoflavone therapy for menopausal flushes: a systematic review and meta-analysis. Maturitas. 2006;55:203-11. CrossRef

69. Tempfer CB, Bentz EK, Leodolter S, et al. Phytoestrogens in clinical practice: a review of the literature. Fertil Steril. 
2007;87:1243-9. CrossRef

70. Lethaby A, Marjoribanks J, Kronenberg F, Roberts H, Eden J, Brown J. Phytoestrogens for menopausal vasomotor symptoms. Cochrane Database Syst Rev. 2013;12:CD001395. CrossRef

71. Unfer V, Casini ML, Costabile L, Mignosa M, Gerli S, Di Renzo GC. Endometrial effects of long-term treatment with phytoestrogens: a randomized, double-blind, placebocontrolled study. Fertil Steril. 2004;82:145-8, quiz 265. CrossRef

72. Kakehashi A, Tago Y, Yoshida M, et al. Hormonally active doses of isoflavone aglycones promote mammary and endometrial carcinogenesis and alter the molecular tumor environment in Donryu rats. Toxicol Sci. 2012;126:39-51. CrossRef

73. Ollberding NJ, Lim U, Wilkens LR, et al. Legume, soy, tofu, and isoflavone intake and endometrial cancer risk in postmenopausal women in the multiethnic cohort study. J Natl Cancer Inst. 2012;104:67-76. CrossRef

74. Bélisle S, Blake J, Basson R, et al. Canadian Consensus Conference on menopause, 2006 update. J Obstet Gynaecol Can. 2006;28:S7-94.

75. Anderson GD, Rosito G, Mohustsy MA, Elmer GW. Drug interaction potential of soy extract and Panax ginseng. J Clin Pharmacol. 2003;43:643-8. CrossRef

76. Cambria-Kiely JA. Effect of soy milk on warfarin efficacy. Ann Pharmacother. 2002;36:1893-6. CrossRef

77. Centers for Disease Control and Prevention (CDC). Botulism associated with home-fermented tofu in two Chinese immigrants-New York City, March-April 2012. MMWR Morb Mortal Wkly Rep. 2013;62:529-32.

78. Kudo T. Warfarin antagonism of natto and increase in serum vitamin K by intake of natto. Artery. 1990;17:189-201.

79. Schurgers LJ, Shearer MJ, Hamulyák K, Stöcklin E, Vermeer C. Effect of vitamin $\mathrm{K}$ intake on the stability of oral anticoagulant treatment: dose-response relationships in healthy subjects. Blood. 2004;104:2682-9. CrossRef

80. Le Bars PL, Katz MM, Berman N, Itil TM, Freedman AM, Schatzberg AF. A placebo-controlled, double-blind, randomized trial of an extract of Ginkgo biloba for dementia. North American EGb Study Group. JAMA. 1997;278:1327-32. CrossRef

81. Ernst E, Stevinson C. Ginkgo biloba for tinnitus: a review. Clin Otolaryngol Allied Sci. 1999;24:164-7. CrossRef

82. Pittler MH, Ernst E. Ginkgo biloba extract for the treatment of intermittent claudication: a meta-analysis of randomized trials. Am J Med. 2000;108:276-81. CrossRef

83. Birks J, Grimley Evans J. Ginkgo biloba for cognitive impairment and dementia. Cochrane Database Syst Rev. 2009;(1):CD003120. $\underline{\text { CrossRef }}$

84. Sierpina VS, Wollschlaeger B, Blumenthal M. Ginkgo biloba. Am Fam Physician. 2003;68:923-6.

85. Cho HJ, Nam KS. Inhibitory effect of ginkgolide B on platelet aggregation in a cAMP- and cGMP-dependent manner by activated MMP-9. J Biochem Mol Biol. 2007;40:678-83. CrossRef

86. Lamant V, Mauco G, Braquet P, Chap H, Douste-Blazy L. Inhibition of the metabolism of platelet activating factor (PAF-acether) by three specific antagonists from Ginkgo biloba. Biochem Pharmacol. 1987;36:2749-52. CrossRef

87. Kim YS, Pyo MK, Park KM, et al. Antiplatelet and antithrombotic effects of a combination of ticlopidine and ginkgo biloba ext (EGb 761). Thromb Res. 1998;91:33-8. $\underline{\text { CrossRef }}$
88. Matthews MK Jr. Association of Ginkgo biloba with intracerebral hemorrhage. Neurology. 1998;50:1933-4. CrossRef

89. Meisel C, Johne A, Roots I. Fatal intracerebral mass bleeding associated with Ginkgo biloba and ibuprofen. Atherosclerosis. 2003;167:367. CrossRef

90. Rosenblatt M, Mindel J. Spontaneous hyphema associated with ingestion of Ginkgo biloba extract. $N$ Engl J Med. 1997;336:1108. CrossRef

91. Fessenden JM, Wittenborn W, Clarke L. Gingko biloba: a case report of herbal medicine and bleeding postoperatively from a laparoscopic cholecystectomy. Am Surg. 2001;67:33-5.

92. Hauser D, Gayowski T, Singh N. Bleeding complications precipitated by unrecognized Gingko biloba use after liver transplantation. Transpl Int. 2002;15:377-9. CrossRef

93. Jiang X, Williams KM, Liauw WS, et al. Effect of ginkgo and ginger on the pharmacokinetics and pharmacodynamics of warfarin in healthy subjects. Br J Clin Pharmacol. 2005;59:425-32. CrossRef

94. Engelsen J, Nielsen JD, Winther K. Effect of coenzyme Q10 and Ginkgo biloba on warfarin dosage in stable, long-term warfarin treated outpatients. A randomised, double blind, placebo-crossover trial. Thromb Haemost. 2002;87:1075-6.

95. Ang-Lee MK, Moss J, Yuan CS. Herbal medicines and perioperative care. JAMA. 2001;286:208-16. CrossRef

96. Lifeline to Modern Medicine. Herbal supplements and anesthesia. http://www.asahq.org/lifeline/anesthesia $\% 20$ topics/herbal\%20supplements $\% 20$ and $\% 20$ anesthesia. Accessed July 23, 2015.

97. Diamond BJ, Shiflett SC, Feiwel N, et al. Ginkgo biloba extract: mechanisms and clinical indications. Arch Phys Med Rehabil. 2000;81:668-78. CrossRef

98. Lin YY, Chu SJ, Tsai SH. Association between priapism and concurrent use of risperidone and Ginkgo biloba. Mayo Clin Proc. 2007;82:1289-90. CrossRef

99. Kupiec T, Raj V. Fatal seizures due to potential herb-drug interactions with Ginkgo biloba. J Anal Toxicol. 2005;29:755-8. CrossRef

100. Galluzzi S, Zanetti O, Binetti G, Trabucchi M, Frisoni GB. Coma in a patient with Alzheimer's disease taking low dose trazodone and gingko biloba. J Neurol Neurosurg Psychiatry. 2000;68:679-80. $\underline{\text { CrossRef }}$

101. Wiegman DJ, Brinkman K, Franssen EJ. Interaction of Ginkgo biloba with efavirenz. AIDS. 2009;23:1184-5. CrossRef

102. Zhao J, Lahiri-Chatterjee M, Sharma Y, Agarwal R. Inhibitory effect of a flavonoid antioxidant silymarin on benzoyl peroxide-induced tumor promotion, oxidative stress and inflammatory responses in SENCAR mouse skin. Carcinogenesis. 2000;21:811-6. CrossRef

103. Milić N, Milosević N, Suvajdzić L, Zarkov M, Abenavoli L. New therapeutic potentials of milk thistle (Silybum marianum). Nat Prod Commun. 2013;8:1801-10.

104. Katiyar SK, Korman NJ, Mukhtar H, Agarwal R. Protective effects of silymarin against photocarcinogenesis in a mouse skin model. J Natl Cancer Inst. 1997;89:556-66. CrossRef

105. Fuhr U, Beckmann-Knopp S, Jetter A, Lück H, Mengs U. The effect of silymarin on oral nifedipine pharmacokinetics. Planta Med. 2007;73:1429-35. CrossRef

106. Beckmann-Knopp S, Rietbrock S, Weyhenmeyer R, et al. Inhibitory effects of silibinin on cytochrome P-450 enzymes in human liver microsomes. Pharmacol Toxicol. 2000;86:250-6. CrossRef 
107. Strunets A, Mirza M, Sra J, Jahangir A. Novel anticoagulants for stroke prevention in atrial fibrillation: safety issues in the elderly. Expert Rev Clin Pharmacol. 2013;6:677-89. CrossRef

108. Burdette JE, Liu J, Chen SN, et al. Black cohosh acts as a mixed competitive ligand and partial agonist of the serotonin receptor. J Agric Food Chem. 2003;51:5661-70. CrossRef

109. Qiu SX, Dan C, Ding LS, et al. A triterpene glycoside from black cohosh that inhibits osteoclastogenesis by modulating RANKL and TNFalpha signaling pathways. Chem Biol. 2007;14:860-9. CrossRef

110. Newton KM, Reed SD, LaCroix AZ, Grothaus LC, Ehrlich K, Guiltinan J. Treatment of vasomotor symptoms of menopause with black cohosh, multibotanicals, soy, hormone therapy, or placebo: a randomized trial. Ann Intern Med. 2006;145:869-79. CrossRef

111. Leach MJ, Moore V. Black cohosh (Cimicifuga spp.) for menopausal symptoms. Cochrane Database Syst Rev. 2012;9:CD007244. CrossRef

112. Davis VL, Jayo MJ, Ho A, et al. Black cohosh increases metastatic mammary cancer in transgenic mice expressing c-erbB2. Cancer Res. 2008;68:8377-83. CrossRef

113. Whiting PW, Clouston A, Kerlin P. Black cohosh and other herbal remedies associated with acute hepatitis. Med J Aust. 2002;177:440-3.

114. Naser B, Schnitker J, Minkin MJ, de Arriba SG, Nolte KU, Osmers R. Suspected black cohosh hepatotoxicity: no evidence by meta-analysis of randomized controlled clinical trials for isopropanolic black cohosh extract. Menopause. 2011;18:366-75. CrossRef

115. Mahady GB, Low Dog T, Barrett ML, et al. United States Pharmacopeia review of the black cohosh case reports of hepatotoxicity. Menopause. 2008;15:628-38. CrossRef

116. Linde K, Barrett B, Wölkart K, Bauer R, Melchart D. Echinacea for preventing and treating the common cold. Cochrane Database Syst Rev. 2006;(1):CD000530. CrossRef

117. Barrett BP, Brown RL, Locken K, Maberry R, Bobula JA, D'Alessio D. Treatment of the common cold with unrefined echinacea: a randomized, double-blind, placebo-controlled trial. Ann Intern Med. 2002;137:939-46. CrossRef

118. Turner RB, Bauer R, Woelkart K, Hulsey TC, Gangemi JD. An evaluation of Echinacea angustifolia in experimental rhinovirus infections. $N$ Engl $J$ Med. 2005;353:341-8. CrossRef

119. Gorski JC, Huang SM, Pinto A, et al. The effect of echinacea (Echinacea purpurea root) on cytochrome P450 activity in vivo. Clin Pharmacol Ther. 2004;75:89-100. CrossRef

120. Huntley AL, Thompson Coon J, Ernst E. The safety of herbal medicinal products derived from Echinacea species: a systematic review. Drug Saf. 2005;28:387-400. CrossRef

121. Gurley BJ, Swain A, Williams DK, Barone G, Battu SK. Gauging the clinical significance of P-glycoprotein-mediated herb-drug interactions: comparative effects of St. John's wort, Echinacea, clarithromycin, and rifampin on digoxin pharmacokinetics. Mol Nutr Food Res. 2008;52:772-9. CrossRef

122. Gurley BJ, Swain A, Hubbard MA, et al. Clinical assessment of CYP2D6-mediated herb-drug interactions in humans: effects of milk thistle, black cohosh, goldenseal, kava kava, St. John's wort, and Echinacea. Mol Nutr Food Res. 2008;52:755-63. CrossRef

123. Abdul MI, Jiang X, Williams KM, et al. Pharmacokinetic and pharmacodynamic interactions of echinacea and policosanol with warfarin in healthy subjects. $\mathrm{Br} J$ Clin Pharmacol. 2010;69:508-15. CrossRef

124. Kocaman O, Hulagu S, Senturk O. Echinacea-induced severe acute hepatitis with features of cholestatic autoimmune hepatitis. Eur J Intern Med. 2008;19:148. CrossRef

125. Abebe W. Herbal medication: potential for adverse interactions with analgesic drugs. J Clin Pharm Ther. 2002;27:391-401. CrossRef

126. Hypericum Depression Trial Study Group. Effect of Hypericum perforatum (St. John's wort) in major depressive disorder: a randomized controlled trial. JAMA. 2002;287:1807-14. CrossRef

127. Linde K, Berner MM, Kriston L. St. John's wort for major depression. Cochrane Database Syst Rev. 2008;(4):CD000448. CrossRef

128. Moore LB, Goodwin B, Jones SA, et al. St. John's wort induces hepatic drug metabolism through activation of the pregnane X receptor. Proc Natl Acad Sci U S A. 2000;97:7500-2. $\underline{\text { CrossRef }}$

129. Piscitelli SC, Burstein AH, Chaitt D, Alfaro RM, Falloon J. Indinavir concentrations and St. John's wort. Lancet. 2000;355:547-8. CrossRef

130. Ernst E. Second thoughts about safety of St. John's wort. Lancet. 1999;354:2014-6. CrossRef

131. Crowe S, McKeating K. Delayed emergence and St. John's wort. Anesthesiology. 2002;96:1025-7.

132. Yue QY, Bergquist C, Gerdén B. Safety of St. John's wort (Hypericum perforatum). Lancet. 2000;355:576-7. CrossRef

133. Sarino LV, Dang KH, Dianat N, et al. Drug interaction between oral contraceptives and St. John's Wort: appropriateness of advice received from community pharmacists and health food store clerks. J Am Pharm Assoc (2003). 2007;47:42-7. CrossRef

134. Goey AK, Meijerman I, Rosing H, et al. The effect of St. John's wort on the pharmacokinetics of docetaxel. Clin Pharmacokinet. 2014;53:103-10. CrossRef

135. Breidenbach T, Hoffmann MW, Becker T, Schlitt H, Klempnauer J. Drug interaction of St. John's wort with cyclosporin. Lancet. 2000;355:1912. CrossRef

136. Ernst E. St. John's Wort supplements endanger the success of organ transplantation. Arch Surg. 2002;137:316-9. CrossRef

137. Mai I, Störmer E, Bauer S, Krüger H, Budde K, Roots I. Impact of St. John's wort treatment on the pharmacokinetics of tacrolimus and mycophenolic acid in renal transplant patients. Nephrol. Dial Transplant. 2003;18:819-22. CrossRef

138. Ruschitzka F, Meier PJ, Turina M, Lüscher TF, Noll G. Acute heart transplant rejection due to Saint John's wort. Lancet. 2000;355:548-9. CrossRef

139. Henderson L, Yue QY, Bergquist C, Gerden B, Arlett P. St. John's wort (Hypericum perforatum): drug interactions and clinical outcomes. Br J Clin Pharmacol. 2002;54:349-56. CrossRef

140. Jiang X, Williams KM, Liauw WS, et al. Effect of St. John's wort and ginseng on the pharmacokinetics and pharmacodynamics of warfarin in healthy subjects. Br J Clin Pharmacol. 2004;57:592-9. CrossRef

141. Uygur Bayramiçli O, Kalkay MN, Oskay Bozkaya E, et al. St. John's wort (Hypericum perforatum) and warfarin: Dangerous liaisons! Turk J Gastroenterol. 2011;22:115.

142. Patel S, Robinson R, Burk M. Hypertensive crisis associated with St. John's Wort. Am J Med. 2002;112:507-8. CrossRef 
143. Moses EL, Mallinger AG. St. John's Wort: three cases of possible mania induction. J Clin Psychopharmacol. 2000;20:115-7.

144. Hammerness P, Basch E, Ulbricht C, et al. St. John's wort: a systematic review of adverse effects and drug interactions for the consultation psychiatrist. Psychosomatics. 2003;44:271-82. CrossRef

145. Qi LW, Wang CZ, Yuan CS. American ginseng: potential structure-function relationship in cancer chemoprevention. Biochem Pharmacol. 2010;80:947-54. CrossRef

146. Henderson GL, Harkey MR, Gershwin ME, Hackman RM, Stern JS, Stresser DM. Effects of ginseng components on c-DNA-expressed cytochrome P450 enzyme catalytic activity. Life Sci. 1999;65:PL209-14. CrossRef

147. Bilgi N, Bell K, Ananthakrishnan AN, Atallah E. Imatinib and Panax ginseng: a potential interaction resulting in liver toxicity. Ann Pharmacother. 2010;44:926-8. CrossRef

148. Mateo-Carrasco H, Gálvez-Contreras MC, Fernández-Ginés FD, Nguyen TV. Elevated liver enzymes resulting from an interaction between Raltegravir and Panax ginseng: a case report and brief review. Drug Metabol Drug Interact. 2012;27:171-5. CrossRef

149. Gurley BJ, Gardner SF, Hubbard MA, et al. Clinical assessment of effects of botanical supplementation on cytochrome P450 phenotypes in the elderly: St. John's wort, garlic oil, Panax ginseng and Ginkgo biloba. Drugs Aging. 2005;22:525-39. CrossRef

150. Kuo SC, Teng CM, Lee JC, Ko FN, Chen SC, Wu TS. Antiplatelet components in Panax ginseng. Planta Med. 1990;56:164-7. CrossRef

151. Park HJ, Lee JH, Song YB, Park KH. Effects of dietary supplementation of lipophilic fraction from Panax ginseng on cGMP and cAMP in rat platelets and on blood coagulation. Biol Pharm Bull. 1996;19:1434-9. CrossRef

152. Teng CM, Kuo SC, Ko FN, et al. Antiplatelet actions of panaxynol and ginsenosides isolated from ginseng. Biochim Biophys Acta. 1989;990:315-20. CrossRef

153. Janetzky K, Morreale AP. Probable interaction between warfarin and ginseng. Am J Health Syst Pharm. 1997;54:692-3.

154. Rosado MF. Thrombosis of a prosthetic aortic valve disclosing a hazardous interaction between warfarin and a commercial ginseng product. Cardiology. 2003;99:111. CrossRef

155. Yuan CS, Wei G, Dey L, et al. Brief communication: American ginseng reduces warfarin's effect in healthy patients: a randomized, controlled trial. Ann Intern Med. 2004;141:23-7. CrossRef

156. Lee SH, Ahn YM, Ahn SY, Doo HK, Lee BC. Interaction between warfarin and Panax ginseng in ischemic stroke patients. $J$ Altern Complement Med. 2008;14:715-21. CrossRef

157. Lee YH, Lee BK, Choi YJ, Yoon IK, Chang BC, Gwak HS. Interaction between warfarin and Korean red ginseng in patients with cardiac valve replacement. Int J Cardiol. 2010;145:275-6. CrossRef

158. Izzo AA, Ernst E. Interactions between herbal medicines and prescribed drugs: asystematic review.Drugs. 2001;61:2163-75. CrossRef

159. Vuksan V, Sievenpiper JL, Koo VY, et al. American ginseng (Panax quinquefolius L) reduces postprandial glycemia in nondiabetic subjects and subjects with type 2 diabetes mellitus. Arch Intern Med. 2000;160:1009-13. CrossRef

160. Caron MF, Hotsko AL, Robertson S, Mandybur L, Kluger J,
White CM. Electrocardiographic and hemodynamic effects of Panax ginseng. Ann Pharmacother. 2002;36:758-63. CrossRef 161. Hellum BH, Hu Z, Nilsen OG. The induction of CYP1A2, CYP2D6 and CYP3A4 by six trade herbal products in cultured primary human hepatocytes. Basic Clin Pharmacol Toxicol. 2007;100:23-30. CrossRef

162. McRae S. Elevated serum digoxin levels in a patient taking digoxin and Siberian ginseng. CMAJ. 1996;155:293-5.

163. Punnonen R, Lukola A. Oestrogen-like effect of ginseng. Br Med J. 1980;281:1110. CrossRef

164. Palmer BV, Montgomery AC, Monteiro JC. Gin Seng and mastalgia. Br Med J. 1978;1:1284. CrossRef

165. Hopkins MP, Androff L, Benninghoff AS. Ginseng face cream and unexplained vaginal bleeding. Am J Obstet Gynecol. 1988;159:1121-2. $\underline{\text { CrossRef }}$

166. Jones BD, Runikis AM. Interaction of ginseng with phenelzine. J Clin Psychopharmacol. 1987;7:201-2. CrossRef

167. Hammond TG, Whitworth JA. Adverse reactions to ginseng. Med J Aust. 1981;1:492.

168. Lilja JJ, Neuvonen M, Neuvonen PJ. Effects of regular consumption of grapefruit juice on the pharmacokinetics of simvastatin. Br J Clin Pharmacol. 2004;58:56-60. CrossRef

169. Pillai U, Muzaffar J, Sen S, Yancey A. Grapefruit juice and verapamil: a toxic cocktail. South Med J. 2009;102:308-9. CrossRef

170. Bailey DG, Dresser GK, Kreeft JH, Munoz C, Freeman DJ, Bend JR. Grapefruit-felodipine interaction: effect of unprocessed fruit and probable active ingredients. Clin Pharmacol Ther. 2000;68:468-77. CrossRef

171. Tomlinson B, Chow MS. Stereoselective interaction of manidipine and grapefruit juice: a new twist on an old tale. Br J Clin Pharmacol. 2006;61:529-32. CrossRef

172. Libersa CC, Brique SA, Motte KB, et al. Dramatic inhibition of amiodarone metabolism induced by grapefruit juice. Br J Clin Pharmacol. 2000;49:373-8. CrossRef

173. Taniguchi K, Ohtani H, Ikemoto T, Miki A, Hori S, Sawada Y. Possible case of potentiation of the antiplatelet effect of cilostazol by grapefruit juice. J Clin Pharm Ther. 2007;32: 457-9. CrossRef

174. Brandin H, Myrberg O, Rundlöf T, Arvidsson AK, Brenning G. Adverse effects by artificial grapefruit seed extract products in patients on warfarin therapy. Eur J Clin Pharmacol. 2007;63:565-70. $\underline{\text { CrossRef }}$

175. U.S. Congress. Act S. 784 (passed Aug. 13, 1994). http://www. gpo.gov/fdsys/pkg/BILLS-103s784es/pdf/BILLS-103s784es. pdf. Accessed September 20, 2015.

176. U.S. Food and Drug Administration. Questions and answers on dietary supplements. http:/www.fda.gov/Food/ DietarySupplements/QADietarySupplements/default.htm. Accessed September 20, 2015.

177. U.S. Food and Drug Administration. Current good manufacturing practices (CGMPs). http://www.fda.gov/food/ guidanceregulation/cgmp/default.htm. Accessed September 20, 2015.

178. Ashar BH. The dietary supplement health and education act: time for a reassessment: comment on "acute selenium toxicity associated with a dietary supplement." Arch Intern Med. 2010;170:261-3. CrossRef

179. Bouchard NC, Howland MA, Greller HA, Hoffman RS, Nelson LS. Ischemic stroke associated with use of an ephedrafree dietary supplement containing synephrine. Mayo Clin Proc. 2005;80:541-5. CrossRef 
180. Gershwin ME, Borchers AT, Keen CL, Hendler S, Hagie F, Greenwood MR. Public safety and dietary supplementation. Ann N Y Acad Sci. 2010;1190:104-17. CrossRef

181. Mills E, Wu P, Johnston BC, Gallicano K, Clarke M, Guyatt G. Natural health product-drug interactions: a systematic review of clinical trials. Ther Drug Monit. 2005;27:549-57. CrossRef

182. Daniele C, Mazzanti G, Pittler MH, Ernst E. Adverse-event profile of Crataegus spp.: a systematic review. Drug Saf. 2006;29:523-35. CrossRef

183. González-Stuart A. Herbal product use by older adults. Maturitas. 2011;68:52-5. CrossRef

184. Gurley BJ, Gardner SF, Hubbard MA, et al. Cytochrome P450 phenotypic ratios for predicting herb-drug interactions in humans. Clin Pharmacol Ther. 2002;72:276-87. CrossRef

185. Institute of Medicine (US) Committee on the Use of Complementary and Alternative Medicine by the American Public. Complementary and alternative medicine in the United States. Washington, DC: National Academies Press (US), 2005.

186. Hu Z, Yang X, Ho PC, et al. Herb-drug interactions: a literature review. Drugs. 2005;65:1239-82. CrossRef

187. Boon HS, Kachan N. Natural health product labels: is more information always better? Patient Educ Couns. 2007;68: 193-9. CrossRef

188. Siegel RK. Ginseng abuse syndrome. Problems with the panacea. JAMA. 1979;241:1614-5. CrossRef

189. Wanwimolruk S, Wong K, Wanwimolruk P. Variable inhibitory effect of different brands of commercial herbal supplements on human cytochrome P-450 CYP3A4. Drug Metabol Drug Interact. 2009;24:17-35. CrossRef

190. Newmaster SG, Grguric M, Shanmughanandhan D, Ramalingam S, Ragupathy S. DNA barcoding detects contamination and substitution in North American herbal products. BMC Med. 2013;11:222. CrossRef

191. Kaplan S. GNC, Target, Wal-Mart, Walgreens accused of selling adulterated 'herbals' (Feb. 3, 2015) http://www. washingtonpost.com/news/morning-mix/wp/2015/02/03/gnctarget-wal-mart-walgreens-accused-of-selling-fake-herbals/. Accessed February 5,2015.

192. Consumer Reports. Alert: protein drinks (July 2010). http://www.consumerreports.org/cro/magazine-archive/ $2010 / \mathrm{july} /$ food/protein-drinks/overview/index.htm. Accessed February 5, 2015.

193. U.S. Food and Drug Administration. Steam dietary supplement (updated Aug. 24, 2009). http://www. fda.gov/Safety/MedWatch/S a fetyInformation/ SafetyAlertsforHumanMedicalProducts/ucm174339.htm. Accessed July 23, 2015.

194. Schoepfer AM, Engel A, Fattinger K, et al. Herbal does not mean innocuous: ten cases of severe hepatotoxicity associated with dietary supplements from Herbalife ${ }^{\circledR}$ products. $J$ Hepatol. 2007;47:521-6. CrossRef

195. Torp-Pedersen C, Caterson I, Coutinho W, et al. Cardiovascular responses to weight management and sibutramine in highrisk subjects: an analysis from the SCOUT trial. Eur Heart J. 2007;28:2915-23. CrossRef

196. Food and Drug Administration Office of Criminal Investigations. Two New Jersey dietary supplement companies and their principals found guilty of criminal contempt (June 2, 2011). http://www.fda.gov/ICECI/CriminalInvestigations/ ucm257815.htm. Accessed February 5, 2015.

197. Morris CA, Avorn J. Internet marketing of herbal products.
JAMA. 2003;290:1505-9. CrossRef

198. Office of Inspector General, U.S. Department of Health \& Human Services. Dietary supplements: structure/function claims fail to meet federal requirements (Oct. 2, 2012). https://oig.hhs.gov/oei/reports/oei-01-11-00210.asp. Accessed February 5, 2015.

199. Office of Inspector General, U.S. Department of Health \& Human Services. Adverse event reporting for dietary supplements. An inadequate safety valve (April 2001). http://oig.hhs.gov/oei/reports/oei-01-00-00180.pdf. Accessed February 5, 2015.

200. Alherbish A, Charrois TL, Ackman ML, Tsuyuki RT, Ezekowitz JA. The prevalence of natural health product use in patients with acute cardiovascular disease. PLoS One. 2011;6:e19623. CrossRef

201. Bailey DG, Dresser GK. Interactions between grapefruit juice and cardiovascular drugs. Am J Cardiovasc Drugs. 2004;4:281-97. CrossRef

202. Harrigan JT. Patient disclosure of the use of complementary and alternative medicine to their obstetrician/gynaecologist. J Obstet Gynaecol. 2011;31:59-61. CrossRef

203. Suchard JR, Suchard MA, Steinfeldt JL. Physician knowledge of herbal toxicities and adverse herb-drug interactions. Eur $J$ Emerg Med. 2004;11:193-7. CrossRef

204. Cellini M, Attipoe S, Seales P, et al. Dietary supplements: physician knowledge and adverse event reporting. Med Sci Sports Exerc. 2013;45:23-8. CrossRef

205. Gardiner P, Sarma DN, Low Dog T, et al. The state of dietary supplement adverse event reporting in the United States. Pharmacoepidemiol Drug Saf. 2008;17:962-70. CrossRef

206. U.S. Food and Drug Administration. Reporting serious problems to FDA (MedWatch, updated Feb. 11, 2014). http://www.fda.gov/medwatch/report/hcp.htm. Accessed September 20, 2015.

207. Harris Interactive ${ }^{\circledR}$. Harris poll shows widespread public ignorance of supplement regulation (Dec. 23, 2002). http:// www.supplementquality.com/news/Harris_survey.html. Accessed February 5, 2015.

208. Fox S, Rainie L, Horrigan J, et al. The online health care revolution: how the Web helps Americans take better care of themselves (Nov. 26, 2000). http://www.pewinternet.org/files/ old-media//Files/Reports/2000/PIP_Health_Report.pdf.pdf. Accessed February 5, 2015.

209. Nazeri A, Massumi A, Wilson JM, et al. Arrhythmogenicity of weight-loss supplements marketed on the Internet. Heart Rhythm. 2009;6:658-62. CrossRef

210. Reinert A, Rohrmann S, Becker N, Linseisen J. Lifestyle and diet in people using dietary supplements: a German cohort study. Eur J Nutr. 2007;46:165-73. CrossRef

211. Cheung CK, Wyman JF, Halcon LL. Use of complementary and alternative therapies in community-dwelling older adults. J Altern Complement Med. 2007;13:997-1006. CrossRef

212. Kwan D, Hirschkorn K, Boon H. U.S. and Canadian pharmacists' attitudes, knowledge, and professional practice behaviors toward dietary supplements: a systematic review. BMC Complement Altern Med. 2006;6:31. CrossRef

213. Glisson JK, Rogers HE, Abourashed EA, Ogletree R, Hufford $\mathrm{CD}$, Khan I. Clinic at the health food store? Employee recommendations and product analysis. Pharmacotherapy. 2003;23:64-72. CrossRef

(C) 2015 Aurora Health Care, Inc. 